\title{
The Impacts of Soy-Based Biodiesel on the Main Soy Producers in the International Market
}

\author{
Augusto Mussi Alvim (Corresponding Author) \\ Pontifical University Catholic of Rio Grande do Sul (PUCRS), Business School \\ Porto Alegre, Rio Grande do Sul, Brazil. E-mail: augusto.alvim@pucrs.br \\ Adelar Fochezatto \\ Pontifical University Catholic of Rio Grande do Sul (PUCRS), Business School \\ Porto Alegre, Rio Grande do Sul, Brazil. E-mail: adelar@pucrs.br
}

Received: Jan. 11, 2020

doi:10.5296/jas.v8i2.16204
Accepted: Mar. 24, $2020 \quad$ Published: Mar. 29, 2020

URL: https://doi.org/10.5296/jas.v8i2.16204

\begin{abstract}
This study analyzes the impacts of soy-based biodiesel consumption on the main soybean-producing countries. To achieve this goal, a partial equilibrium model formulated as a Mixed Complementarity Problem (PCM) is used, which allows the inclusion of trade barriers and the construction of alternative scenarios. Four scenarios are analyzed. The first simulates a demand shock for soybean meal and soybean oil, considering the observed growth in demand over the last ten years. The second evaluates the effects of an increase in the demand for meal, oil and biodiesel. The third considers the elimination of the demand for soy-based biodiesel. The last scenario assesses the effects of the elimination of tariffs and subsidies on the grain and food markets. In general terms, the results show that: in the second scenario, Brazil is the only exporting country that shows a greater increase in consumption than in production, reflecting the country's smaller share in the world soybean trade; in the fourth scenario the gains are relatively smaller than the potential gains in the first scenario; in the third scenario, soybean prices are about $8 \%$ higher because of the use of soybeans for biodiesel production, demonstrating the relevance of mandatory policies in this market.
\end{abstract}

Keywords: biodiesel, soybean meal and oil, international trade, MCP

JEL: Q17. 


\section{Introduction}

Although agricultural activity uses electricity and oil products as input for food production, the relationship between these markets has always been considered small when compared to other sectors of the economy. With the growth of biofuel and renewable energy production from biomass, the interaction between the two markets has increased in recent decades, resulting in changes in production, consumption, cultivated area and in the prices of food and agricultural products.

The production of biofuels includes ethanol and biodiesel, which are alternatives to the use of petroleum derivatives. This production was stimulated initially by the increase in fuel demand, fuel price increases and a set of policies designed to encourage the production and consumption of biofuels. This new reality has provided more favorable conditions for the use of new sources of renewable energy, in particular bioenergy (Popp et al, 2014).

Worldwide, biodiesel production is concentrated in the countries of the European Union (mainly in France and Germany), Asia (mainly Indonesia and Malaysia), the USA, Brazil and Argentina. The main raw material used in the production of biodiesel differs between regions: in the European Union (EU) it is canola oil; in Asia, it is palm and coconut oil; and soybean oil and animal fat are used in the USA, Brazil and Argentina (Popp et al, 2014, Naylor and Higgins, 2018).

Associated with the increase in demand and the potential for expansion of the bioenergy market in world terms, there is also an increase in the demand for meal and vegetable oil for human consumption. With the rapid growth of income in developing countries, there was an increase in meat demand, which in turn stimulated the production of meal and vegetable oils (Martin, 2019).

The high demand for meal, oil, food and biodiesel resulted in growth in soybean production and trade, reflecting in higher prices on the international market. In this scenario, soybean production in Brazil grew at a rate of $7 \%$ per year, with a $4 \%$ increase in planted area, considering the period from 1990 to 2011 (Fliehr, 2013).

Thus, the present study evaluates the effects of increased demand for biodiesel, meal and vegetable oil on the soybean market in the main producing and consuming regions of this product. The study also examines the potential gains from the elimination of tariff barriers and subsidies in the soybean and derivatives market (biodiesel, meal and oil). In the scenario of greater demand for soybeans and derivatives, a favorable environment is created for the readjustment of US and EU agricultural policies, providing an opportunity for new trade negotiations that allow greater access to the agricultural products market.

Following this introduction, the article is organized into three sections. The second section describes the material and methods, the database and the characterization of the alternative scenarios. The third section presents the soybean complex, the production of biodiesel in the main producing countries and discusses the results. Finally, there are some comments regarding the main conclusions. 


\section{Material and Methods}

The programming model used in this study involves a formulation presented in the form of a Mixed Complementarity Problem (PCM), as proposed by Rutheford (1995), Bishop, Nicholson and Pratt (2001), Nicholson and Bishop (2004) and Oliveira and Alvim (2016). The functions of supply of an agricultural product (producer level) and demand (consumer level) in each region for multiproducts are taken into account. Together with transport costs between regions, in the presence of trade barriers, it is possible to estimate the quantities produced and consumed, trade flows and equilibrium prices. For each product analyzed, it is assumed that the prices, quantities offered and demanded and the trade flows are endogenous variables. Other factors, such as technology, processing costs, product composition, preferences and population growth are variables exogenous to the model.

Table 1 below presents the notation used and the definition of variables for model implementation. The set of equations presented below corresponds to the MCP and represents the conditions for obtaining prices, quantities produced and consumed and trade flows between the regions, taking into account the tariffs, tariff quotas and subsidies applied in the markets.

Table 1. Variables used in the programming model

\begin{tabular}{|c|c|}
\hline$q_{i}^{s}$ & Quantity of soybean in region i (endogenous variable). \\
\hline$q_{j, k, m}^{c}$ & $\begin{array}{l}\text { Quantity of } \mathrm{m} \text { soybean components received by industry } \mathrm{k} \text { of region } \mathrm{i} \text {. The product } \\
\text { received reaches the industry in the non-benefited form (endogenous variable). }\end{array}$ \\
\hline$q_{i, k, m}^{p r c}$ & $\begin{array}{l}\text { Quantity of } \mathrm{m} \text { components of products benefited in industry } \mathrm{k} \text {, in region i (endogenous } \\
\text { variable). }\end{array}$ \\
\hline$q_{i, k}^{p r d}$ & $\begin{array}{l}\text { Quantity of benefited products produced in industry } \mathrm{k} \text {, in region } \mathrm{i} \text {. The existence of } \\
\text { this variable is necessary to include the processing costs for each unit produced } \\
\text { (endogenous variable). }\end{array}$ \\
\hline$q_{j, k}^{d}$ & $\begin{array}{l}\text { Demanded quantity of } \mathrm{k} \text { products (meal, oil and biodiesel) in region } \mathrm{j} \text { (endogenous } \\
\text { variable). }\end{array}$ \\
\hline$X_{i, j, k}$ & Soybean trade flow between region $\mathrm{i}$ and industry $\mathrm{k}$, in region $\mathrm{j}$ (endogenous variable). \\
\hline$X f_{i, j, k, l}$ & $\begin{array}{l}\text { Trade flow of meal, oil and biodiesel between industry } \mathrm{k} \text { in region } \mathrm{i} \text { and consumers in } \\
\text { region } \mathrm{j} \text { (endogenous variable). }\end{array}$ \\
\hline$t_{i, j}^{L}$ & Cost of transporting soybean from region i to region $\mathrm{j}$ (exogenous variable). \\
\hline$t_{i, j, k}^{D}$ & $\begin{array}{l}\text { Cost of transporting meal, oil and biodiesel from region } \mathrm{i} \text { to the region } \mathrm{j} \text { from milk } \\
\text { derivatives (exogenous variable). }\end{array}$ \\
\hline
\end{tabular}


$\operatorname{tar}_{i, j}^{L} \quad$ Tariff imposed on soybean originating in region $\mathrm{i}$ in region $\mathrm{j}$ (exogenous variable). \begin{tabular}{l|l}
$\operatorname{tar}_{i, j, k}^{D}$ & $\begin{array}{l}\text { Tariff imposed on meal, oil and biodiesel originating in region } \mathrm{i} \text { in region } \mathrm{j} \text { (exogenous } \\
\text { variable). }\end{array}$
\end{tabular}

$c p_{i, k} \quad$ Costs of industries benefiting products in i regions (exogenous variable).

$s r_{i, m} \quad$ Proportion of $\mathrm{m}$ components of soybean in region i (exogenous variable).

\begin{tabular}{l|l}
\hline$s f_{i, k, m}$ & $\begin{array}{l}\text { Proportion of } \mathrm{m} \text { components of products benefited in industry } \mathrm{k}, \text { in region } \mathrm{i} \\
\text { (exogenous variable). }\end{array}$
\end{tabular}

(exogenous variable).

\begin{tabular}{l|l}
\hline$\varphi_{i}$ & $\begin{array}{l}\text { Lagrange multiplier: shadow price of soybean in producing region i (endogenous } \\
\text { variable). }\end{array}$ \\
\hline & Lagrange multiplier: shadow price of m agricultural product components received by
\end{tabular}

$\lambda_{j, k, m} \quad$ Lagrange multiplier: shadow price of $\mathrm{m}$ agricultural product components received by industry $\mathrm{k}$ in region $\mathrm{j}$ (endogenous variable).

\begin{tabular}{l|l}
\hline$\sigma_{i, k, m}$ & Lagrange multiplier: shadow price of m components of meal, oil and biodiesel in
\end{tabular} industry $\mathrm{k}$, in region $\mathrm{i}$ (endogenous variable).

$\pi_{i, k} \quad$ Lagrange multiplier: shadow price of meal, oil and biodiesel in $\mathrm{k}$ plants, in region $\mathrm{i}$ \begin{tabular}{l|l}
$\pi_{i, k}$ & (endogenous variable). \\
\hline$\delta_{j, k}$ & Lagrange multiplier: shadow price in consumer region $\mathrm{j}$ (endogenous variable).
\end{tabular}

\begin{tabular}{ll}
$\alpha_{i} \quad$ Constant term of the supply function (exogenous variable). \\
\hline
\end{tabular}

$\varepsilon_{i} \quad$ Price elasticity of the supply function (exogenous variable).

$\beta_{i} \quad$ Constant term of the demand function (exogenous variable).

$\mu_{i} \quad$ Price elasticity of the demand function (exogenous variable).

Source: prepared by the authors.

Equations (1) to (5) are fundamental to delimit the results of the model. Along with an appropriate objective function, they are equivalent to Samuelson-Takayama-Judge's classical primal formulation of the spatial and vertical equilibrium model. Equations (6) to (11) are equivalent to the classical dual formulation, here presented as a PCM. 
Considering the first equation, we observe that $\varphi_{i}$ is a complementary variable to the expression that restricts the sum of the exports of the agricultural product in question from the $i$-th region to the total produced in that region $i$, and represents the shadow price in the producing region $i$. Similarly, the second equation presents a variable $\lambda_{j, k, m}$ which is complementary to the expression that restricts the quantity of $m$ components of the agricultural product that is received by the $k$-th industry in region $j$, and represents the shadow price of $m$ components of the agricultural product acquired by the industry.

Formulation of the Mixed Complementarity Problem:

$$
\begin{array}{ll}
\varphi_{i} \geq 0, & \left(\sum_{j}^{J} \sum_{k}^{K} X_{i, j, k}-q_{i}^{s}\right) \cdot \varphi_{i}=0, \forall i, k \\
\lambda_{j, k, m} \geq 0, \quad & \left(q_{j, k, m}^{c}-\sum_{i}^{I}\left(s r_{j, m} \cdot X_{i, j, k}\right) \cdot \lambda_{j, k, m}=0, \forall j, k, m\right. \\
\sigma_{i, k, m} \geq 0 & \left(\sum_{j}^{J} \sum_{l}^{L} X f_{i, j, k, l}-q_{i, k, m}^{p r c}\right) \cdot \sigma_{i, k, m}=0, \forall i, k, m \\
\pi_{i, k} \geq 0, & \left(\sum_{j}^{J} \sum_{k}^{K} X f_{i, j, k, l}-q_{i, k}^{p r d}\right) \cdot \pi_{i, k}=0, \forall i, k \\
\delta_{j, k} \geq 0, & \left(q_{j, k}^{d}-\sum_{i}^{I} \sum_{l}^{L} X f_{i, j, k, l}\right) \cdot \delta_{j, k}=0, \forall j, k \\
q_{i}^{s} \geq 0, & \left(\left(\frac{q_{i}^{s}}{\alpha_{i}}\right)^{1 / \delta_{i}}-\varphi_{i}\right) \cdot q_{i}^{s}=0, \forall i \\
q_{j, k}^{d} \geq 0, & \left(\delta_{j, k}^{p r d} \geq 0, \quad\left(\frac{q_{j, k}^{d}}{\beta_{j, k}}\right)^{1 / \mu_{j, k}}\right) \cdot q_{j, k}^{d}=0, \forall i, j, k \\
X_{i, j, k} \geq 0, \quad\left(c p_{i, k}-\pi_{i, k}\right) \cdot q_{i, k}^{p r d}=0, \forall i, k \\
\left.q_{i, k, m}^{p r c} \geq 0, \quad\left(\varphi_{i}+t_{i, j}^{L}\right) \cdot\left(1+t a r_{i, j}^{L}\right)-\sum_{m}^{M}\left(s r_{j, m} \cdot \lambda_{j, k, m}\right)\right) \cdot X_{i, j, k}=0, \forall i, j, k \\
\left(\lambda_{j, k, m}-\sigma_{i, k, m}\right) \cdot q_{i, k, m}^{p r c}=0, \forall i, k, m
\end{array}
$$




$$
X f_{i, j, k, l} \geq 0, \quad\left(\left(\left(\sum_{m}^{M} s f_{i, k, m} \cdot \sigma_{i, k, m}\right)+\pi_{i, k}+t_{i, j, k}^{D}\right)\left(1+\operatorname{tar}_{i, j, k}^{D}\right)-\delta_{j, k}\right) \cdot X f_{i, j, k, l}=0, \forall i, j, k, l
$$

Equation (3) ensures that the marketed quantity of agricultural product components with the final consumer cannot exceed the quantity processed in the industry. The variable is complementary to this expression and represents the shadow price of $m$ components of processed products in the industry. Equation (4) allows the model to calculate the quantity of $m$ components in the products processed by the industry, which makes it possible to calculate the per-unit processing cost of the final product, equivalent to the shadow price.

In equation (5), the variable $\delta_{j, k}$ is complementary to the expression that restricts the sum of imports of products derived from the $j$-th industry to the total consumed in region $j$. In other words, the demanded quantity of derivatives cannot be greater than the amount marketed in this region.

For equation (6), when the quantity offered $q_{i}^{s}$ is greater than or equal to zero, the price that producers of the agricultural product are interested in selling should be greater or equal to the market price. Equation (7) defines the conditions for trade between producers and industries. For trade to occur, the market price of the agricultural product (plus transport cost and tariffs) should be equal to the price of the agricultural product in industry $k$. The price of the agricultural product in the industry is calculated based on the sum of the value of the components $\left(\lambda_{j, k, m}\right)$ multiplied by the composition of the product received by the industry.

Equation (8) represents the profit-maximizing behavior of the processing industries. In other words, when the quantity processed $q_{i, k, m}^{p r c}$ by the industry is greater than zero, the prices paid for the components present in the agricultural product must be equal to the prices of $m$ components of the processed products in industry $k$.

Equation (9) determines that when the production of the $k$ industries $\left(q_{i, k}^{p r d}\right)$ is greater than zero, the processing cost of each product unit must be equal to the shadow price associated with this processing activity. Otherwise, when the cost of processing is greater than the shadow price, the amount produced by the industry will be zero.

The study area covers the world market for soybeans, meal, oil and soy-based biodiesel, including all producing, exporting, importing and consuming countries. To enable the modeling process and scenario analysis, some countries are grouped into regions. The criterion for choice takes into account the relevance in terms of production, imports and exports, as well as the regions with the greatest commercial interest for Brazil. 
The selected countries and regions include the main producers, Argentina, Brazil and the US, and the main consumers to China and the European Union (EU). The other countries and regions are grouped in the group in 'Rest of the World'. Prices, consumed and supplied quantities of soy, meal and oil for model implementation are obtained from the OECD/FAO (2015) database.

The quantities of soy-based biodiesel consumed are estimated from the OECD/FAO (2015). The total amount of soy-based biodiesel consumed is not available for all the analyzed regions. Therefore, in order to estimate the amount of soy-based biodiesel consumed, the percentage of soybean consumption was used in relation to the total oilseeds consumed. Biodiesel prices are obtained from the Kingsman Energy from Nature database.

Price elasticities of supply and demand are also used. These are needed to define the supply and demand functions and are obtained from the United States Department of Agriculture Economic Research Service (USDA-ERS, 2014) and the Food and Agriculture Policy Research Center (FAPRI, 2014).

The total transport costs between the regions under study were calculated on the basis of the cost of transporting one ton of bulk product, maritime refrigerated transport (US\$ / sea miles) and distances (sea miles) between study countries/regions. This information was obtained from the USDA. The processing costs of transforming soybean into meal and vegetable oil were obtained from Mandarino, Hirakuri and Roessing (2015) and were considered the same for all regions in the study. Biodiesel processing costs were obtained from Barros et al (2006).

The proportion of soybean components $\left(s r_{i, m}\right)$ and of those used in industry (meal and oil) is available in Gelder, Kammeraat and Kroes (2008). The proportion of biodiesel components in industry was calculated from Barros et al (2006).

Since there is no common tariff in all the countries belonging to the regions defined in the study area, the average tariffs of the importing countries of the chosen blocks or regions were used. Tariffs and subsidies were obtained from the United Nations Conference on Trade and Development (UNCTAD, 2013); United States Department of Agriculture - Economic Research Service (USDA-ERS, 2014); and The International Customs Tariff Bureau (BITD, 2015).

Based on these variables, the baseline scenario was calibrated to adequately represent the production, consumption and trade in the analyzed regions. From this scenario, four scenarios were simulated: in Scenario 1 a simulation of a demand shock of soybean meal and soybean oil was made; Scenario 2 simulates a demand shock for meal, soybean oil and biodiesel; Scenario 3 simulates the elimination of biodiesel demand, supposing the elimination of mandatory biofuel production policies and other policies designed to stimulate the production and consumption of biofuels; and in Scenario 4 a simulation of free trade is made, with the elimination of tariffs and subsidies. In order to analyze the behavior of soybean prices in the face of the scenario changes, the effects were compared of differential demand shocks on soybean meal, oil and soy-based biodiesel $(5 \%, 20 \%$ and 50\%) with the scenario of no consumption and production of biodiesel and free trade. 


\section{Results Analysis}

In the results section, initially the soybean and biodiesel market are described. Afterward the baseline scenario and model calibration are presented, comparing the prices and quantities produced and consumed in the soybean and derivatives market (observed) with the corresponding values estimated by the partial equilibrium model. The results are presented for the alternative scenario, where the variations in terms of soybean production and consumption of soybean meal, oil and soy-based biodiesel are presented. Finally, in the results of sensitivity analysis, the effects of changes in supply and demand elasticities on the production and consumption of soybeans and derivatives are evaluated.

\subsection{The Soybean and Biodiesel Market}

Table 2 shows the total volume of biodiesel (from all sources) produced, consumed and traded in the international market. The regions are defined considering their relevance in terms of production and consumption of soybeans and derivatives. For this reason, although Indonesia and Malaysia have a relevant biodiesel production, these countries are included in 'Others'.

Soybean production worldwide is concentrated in three countries, the USA, Brazil and Argentina, which produce $80.34 \%$ of the world total. According to information from the OECD/FAO (2015), Brazil is the largest net exporter of soybeans (38,919 thousand tons), followed by the USA (36,992 thousand tons) and Argentina (10,181 thousand tons). On the other hand, the largest net importers of the grain are China (62,940 thousand tons) and the EU (12,663 thousand tons). Together, Argentina, Brazil, the US, the EU and China consume $81.88 \%$ of the world total (Table 2).

Soybean meal is one of the major by-products of soybeans and plays an important role in the animal feed industry, especially for poultry and pigs. For the period 2011-2013, the largest producers of this product were China (28.0\%), the USA (20.0\%), Brazil (15.4\%) and Argentina (14.9\%), representing $83.9 \%$ of the world total. Regarding the consumption of meal, China, the EU, the USA and Brazil account for $66.5 \%$ of the world total. This regional concentration in the consumption of meal is due to its use as feed for chickens and pigs, with notable production levels in these regions (Table 2).

Oil production is similar to meal distribution in terms of market share. The world's largest producers of this product are China (26.7\%), the USA (20.7\%), Brazil (16.1\%) and Argentina $(15.3 \%)$. However, there are differences in oil consumption, mainly between the EU and China, resulting in a net export of 486 thousand tons of soybeans from the EU and an import of 1,124 thousand tons to China (Table 2). 
Table 2. Net production, consumption and net exports of soy, meal and oil (thousand tons), Biodiesel (in oil equivalent, thousand tons) - average 2011-2013

\begin{tabular}{|c|c|c|c|c|c|c|}
\hline Variables & Argentina & Brazil & EUA & EU & China & Others \\
\hline Soybean Production & 47,800 & 78,400 & 86,157 & 1,132 & 13,245 & 37,597 \\
\hline Soybean Consumption & 37,619 & 39,481 & 49,165 & 13,796 & 76,185 & 47,846 \\
\hline Net Soybean Exports & 10,181 & 38,919 & 36,992 & $-12,663$ & $-62,940$ & $-10,249$ \\
\hline Meal Production & 27,309 & 28,300 & 36,767 & 10,279 & 51,420 & 29,620 \\
\hline Meal Consumption & 1,537 & 14,266 & 27,217 & 28,429 & 50,020 & 59,006 \\
\hline Net Meal Exports & 25,772 & 14,034 & 9,549 & $-18,150$ & 1,400 & $-29,386$ \\
\hline Oil Production & 6,663 & 7,010 & 9,025 & 2,485 & 11,625 & 6,790 \\
\hline Oil Consumption & 2,675 & 5,563 & 8,460 & 1,999 & 12,749 & 11,939 \\
\hline Net Oil Exports & 3,988 & 1,447 & 565 & 486 & $-1,124$ & $-5,149$ \\
\hline Biodiesel Production & 1,869 & 2,204 & 3,432 & 7,490 & 664 & 4,352 \\
\hline Biodiesel Consumption & 814 & 2,223 & 3,191 & 9,151 & 664 & 3,621 \\
\hline Net Biodiesel Exports & 1,055 & -20 & 242 & $-1,661$ & 0 & 731 \\
\hline
\end{tabular}

Source: OCDE/FAO, 2015.

China, despite producing a small share of the world's soybeans, is the world's largest producer and consumer of soybean meal and soybean oil. This is due to the strong growth of the soybean and meat industry in this country, which produces meal for animal production and oil for human consumption. In the period 2011-2013, China imported about $70 \%$ of the total soybean traded in the world and exported a surplus of meal to the other regions, although it was still necessary to import part of the soybean oil consumed in its market (Table 2). 
The soybean industry is also important for biodiesel production, directly from soybean oil and, indirectly, from the use of animal fat from poultry, pork and cattle that consume meal and produce fat to be used in the biodiesel production. Besides soybeans the other options for biodiesel production are: palm, palm kernel, cottonseed, canola, sunflower, coconut, peanut and animal fat. Soybean oil is most widely used for the production of biodiesel in Argentina, the USA and Brazil, while the EU uses mainly canola oil and Asia, palm and coconut.

The world's biodiesel production is concentrated in the EU countries, in 'Others' and the USA, according to Table 2. Among the largest exporters of biodiesel are Argentina, the USA and 'Others'. On the other hand, the largest consumer and net importer of biodiesel is the EU. Brazil and China produce biodiesel to meet existing domestic demand, with no significant deficits or surpluses (OECD/FAO, 2015).

In Brazil, most of the biodiesel (about $80 \%$ ) is produced from soybean oil. The soybean crushing process results in the separation of oil (18.6\%) and meal (78.7\%). The conversion of soybean oil into biodiesel is carried out from the reaction of the oil with alcohol, with glycerin as a byproduct. Glycerin is commercialized and used in the production of several products, among which we can highlight: resin, cosmetics, detergents, antifreeze and in the pharmaceutical industry (PRADHAN et al, 2011).

Agricultural and commercial policies also help to define the market dynamics for soybean and its derivatives. In terms of agricultural policy, the main mechanism used to stimulate production is transfers or subsidies to soybean production. In the selected countries, there are differences in terms of values and in the form of transfer of this financial support to production. The transfers made by Brazil, the United States and Argentina to their producers may be through subsidized interest rates, that is, the difference between the market lending rate and the effective payment at the time of settlement of the operation by the borrower. Of the three countries, this type of transfer is most widely adopted in Brazil. The United States also provides subsidies for the soybean production in the form of direct payments and countercyclical payments.

In terms of trade policies in the international market, according to the WTO (2011), Brazil and Argentina are the countries that apply the highest import tariffs for soybeans, equivalent to US $\$ 0.08$ per kilogram of the grain. China, on the other hand, is the country that applies the lowest tariff, which is US \$ 0.03 per kilogram of the oilseed. The United States and the EU do not use tariff policy in their markets, but subsidize the product.

From the late 1990s, China introduced a set of policies to increase the competitiveness of the soybean industry and increase the production of soybean meal and soybean oil. Some measures are: the reimbursement of VAT for exporters; exemption from taxes on land transport; reduction of income tax for companies investing in China; and financial support for the oilseed industry (LÓPEZ, RAMOS, SIMKIEVICH, 2008).

These policies have allowed China to consolidate a soybean agro-industrial complex leading to a greater meal and oil production. This has resulted in the country being the world's largest importer of soybeans. According to Nassar et al. (2011), the Chinese strategy attracted soybean 
processing companies such as Cargill, Bunge \& Born, ADM and Louis Dreyfus, which in turn has caused soybeans imports to increase by $280 \%$ in the last ten years.

For biodiesel, government policies play a crucial role in stimulating and enabling production and consumption in the world. Among the most important are the mandatory policies that stipulate a minimum percentage of biodiesel in commercialized diesel, tariff barriers and subsidies for biodiesel production. Regarding the percentage of biodiesel in the mixture with diesel, on average countries require a minimum blend of $5 \%$ biodiesel. The second form of stimulus to the production of biofuels comes from the tariff regime. In the EU, there is a $6.5 \%$ tariff on imported biodiesel, while in the USA there is an import tariff of $4.5 \%$ (JOSLING, BLANDFORD and EARLEY, 2010). The authors also estimate total subsidies for biodiesel in the US and EU of US \$ 0.5-0.6 billion and US \$ 3.1 billion, respectively, for the year 2006 .

\subsection{Base Scenario and Model Calibration}

Partial equilibrium models are validated by comparing the results obtained with the market situation. For the present study, when the variables production, consumption and prices were evaluated, the maximum difference found between the estimated and observed values is $9 \%$. According to Paris, Drogué and Anania, (2011), there are several reasons why the results may not be identical to those observed. These include: the existence of unobservable costs, the occurrence of measurement errors when estimating demand and supply functions and differences in terms of marketed products. In this context, small differences between the observed and estimated values, which do not invalidate the model, may occur. In this way, the model can be validated using the base scenario, since the results are consistent with the data observed in the real world.

Table 3 presents the main producers and consumers of soybeans and derivatives in the period 2011 to 2013. For the baseline scenario, soybean production is concentrated in three countries: The United States (33.82 \%), Brazil (28.97\%) and Argentina (17.89\%). As discussed earlier, soybeans can be processed and consumed as meal, vegetable oil and biodiesel. Meal consumption is higher in countries with significant livestock production, such as China, EU, USA and Brazil, which have market shares of $28.67 \%, 19.44 \%, 12.85 \%$ and $8.03 \% \%$, respectively. 
Table 3. Soybean production and consumption of soybean meal, oil and soy-based biodiesel in the base scenario (average 2011-2013)

\begin{tabular}{l|c|c|c|c|c|c|c|c}
\hline \multirow{2}{*}{ Countries } & \multicolumn{2}{|c|}{ Production } & \multicolumn{2}{c|}{ Meal consumption } & \multicolumn{2}{c|}{ Oil consumption } & \multicolumn{2}{c}{$\begin{array}{c}\text { Biodiesel } \\
\text { consumption }\end{array}$} \\
\cline { 2 - 9 } & $1000 \mathrm{t}$. & $\%$ & $1000 \mathrm{t}$. & $\%$ & $1000 \mathrm{t}$. & $\%$ & $1000 \mathrm{t}$. & $\%$ \\
\hline Argentina & $46,133.33$ & 17.89 & $1,270.00$ & 0.72 & $2,605.00$ & 6.23 & 665.77 & 8.68 \\
Brazil & $74,600.00$ & 28.93 & $14,083.33$ & 8.03 & $5,376.33$ & 12.85 & $2,156.76$ & 28.11 \\
USA & $85,915.00$ & 33.32 & $27,461.00$ & 15.66 & $8,133.67$ & 19.44 & $2,509.56$ & 32.71 \\
EU & $1,122.00$ & 0.44 & $29,248.33$ & 16.68 & $2,182.33$ & 5.22 & $1,885.06$ & 24.57 \\
China & $14,205.00$ & 5.51 & $46,969.33$ & 26.79 & $11,999.33$ & 28.67 & 205.83 & 2.68 \\
RW & $35,859.33$ & 13.91 & $56,301.67$ & 32.11 & $11,550.00$ & 27.60 & 248.42 & 3.24 \\
Total & $257,834.66$ & 100.00 & $175,333.66$ & 100.00 & $41,846.66$ & 100.00 & $7,671.40$ & 100.00 \\
\hline
\end{tabular}

Source: research results.

Considering the selected regions, vegetable oil consumption is more significant in China, the USA and Brazil, as shown in Table 3. China is the largest consumer of soybean oil in the world with 11.99 million tons, equivalent to $28.67 \%$ of the total consumed in the world.

Finally, consumption of soy-based biodiesel is higher in the USA, Brazil and the EU, with a worldwide share of $32.71 \%, 28.11 \%$ and $24.57 \%$, respectively. This higher consumption of soy-based biodiesel is due to the greater availability of raw materials in Brazil and the USA and to the incentive policies adopted in all the considered regions (Table 3 ).

\subsection{Alternative Scenarios}

The first scenario presented in Table 4 simulates a $20 \%$ demand shock on soybean meal and soybean oil, while maintaining the demand for biodiesel constant. In general terms, soybean production increased by around $9 \%$ for most of the regions considered, leading to an increase of $11.54 \%$ in the production of soybeans in China. This increase in soybean supply is due to the higher demand for oil and meal simulated in this scenario. The expansion in the demand for meal and oil causes an increase in meal and oil prices and, consequently, in the prices of the biodiesel. The increase in biodiesel prices leads to a reduction in the demand for biodiesel, clearly showing the substitution effect between vegetable oil (food) and biodiesel (fuel). 
Table 4. Variation in soybean production and consumption of meal, oil and biodiesel in alternative scenarios

\begin{tabular}{|c|c|c|c|c|c|c|c|c|}
\hline \multirow{2}{*}{ Countries } & \multirow{2}{*}{$\begin{array}{l}\text { Production } \\
\text { variation } \\
(\%)\end{array}$} & \multicolumn{3}{|c|}{ Variation on consume $(\%)$} & \multicolumn{4}{|c|}{ Price variation $(\%)$} \\
\hline & & Meal & Oil & Biodiesel & Soy & Meal & Oil & Biodiesel \\
\hline \multicolumn{9}{|c|}{ Scenario 1 - demand shock on food } \\
\hline Argentina & 9.10 & 9.25 & 9.31 & -16.31 & 31.33 & 30.81 & 30.57 & 22.72 \\
\hline Brazil & 9.51 & 9.41 & 15.36 & -16.31 & 30.64 & 30.29 & 30.05 & 22.43 \\
\hline USA & 8.39 & 9.78 & 14.95 & -16.71 & 28.67 & 28.96 & 28.79 & 21.72 \\
\hline EU & 8.13 & 7.23 & 9.17 & -16.84 & 28.67 & 28.42 & 28.26 & 21.42 \\
\hline China & 11.54 & 10.35 & 9.61 & -22.99 & 27.29 & 27.05 & 26.92 & 19.98 \\
\hline RW & 9.41 & 13.02 & 9.60 & -17.58 & 27.53 & 27.11 & 26.95 & 20.66 \\
\hline
\end{tabular}

Scenario 2 - Demand shock on food and biofuels

\begin{tabular}{l|c|ccc|cccc}
\hline Argentina & 9.60 & 8.72 & 8.78 & -0.54 & 33.33 & 32.85 & 32.44 & 24.11 \\
Brazil & 10.03 & 8.88 & 15.13 & -0.53 & 32.60 & 32.29 & 31.88 & 23.80 \\
USA & 8.85 & 9.27 & 14.69 & -1.03 & 30.50 & 30.60 & 30.55 & 23.05 \\
EU & 8.58 & 6.60 & 8.63 & -1.19 & 30.28 & 30.03 & 29.99 & 22.73 \\
China & 12.18 & 9.86 & 9.08 & -8.90 & 29.00 & 28.78 & 28.51 & 21.22 \\
RW & 9.93 & 12.66 & 9.07 & -2.14 & 29.30 & 28.64 & 28.60 & 21.92 \\
\hline
\end{tabular}

\begin{tabular}{|c|c|c|c|c|c|c|c|c|}
\hline \multicolumn{9}{|c|}{ Scenario 3 - without biodiesel production } \\
\hline Argentina & -3.21 & 3.57 & 3.54 & -- & -9.52 & -9.30 & -9.45 & -- \\
\hline Brazil & -3.33 & 3.50 & 1.48 & -- & -9.56 & -9.14 & -9.29 & -- \\
\hline USA & -2.93 & 3.35 & 1.60 & -- & -8.72 & -9.02 & -8.90 & -- \\
\hline EU & -2.84 & 4.23 & 3.54 & -- & -8.94 & -8.85 & -8.74 & -- \\
\hline China & -3.92 & 3.11 & 3.37 & -- & -8.53 & -8.44 & -8.37 & -- \\
\hline RW & -3.24 & 2.22 & 3.37 & -- & -8.37 & -8.44 & -8.33 & -- \\
\hline \multicolumn{9}{|c|}{ Scenario 4 - elimination of tariff barriers and subsidies } \\
\hline Argentina & 0.31 & -0.33 & -0.33 & -0.61 & 1.00 & 1.16 & 1.05 & 0.78 \\
\hline Brazil & 0.18 & -0.32 & -0.14 & -0.60 & 0.49 & 1.14 & 0.92 & 0.68 \\
\hline USA & -0.65 & -0.24 & -0.12 & -0.48 & -1.83 & 0.55 & 0.66 & 0.50 \\
\hline EU & 0.23 & -0.62 & -0.52 & -0.99 & 0.69 & 1.34 & 1.40 & 1.06 \\
\hline China & -0.72 & 0.56 & 0.60 & -0.68 & -1.71 & -1.49 & -1.60 & 0.41 \\
\hline RW & 0.35 & -0.23 & -0.35 & -0.73 & 1.10 & 1.02 & 0.93 & 0.71 \\
\hline
\end{tabular}

Source: research results

Scenario 2 considers a positive $20 \%$ shock in the demand for meal, oil and biodiesel. The changes in soybean production are slightly higher than those in scenario 1, with production 
varying from $8.58 \%$ in the EU to $12.18 \%$ in China. Due to the simulation of a simultaneous demand shock in the meal, oil and biodiesel, smaller variations are seen in the consumption of meal and oil (Table 4).

However, in the case of biodiesel there is a more significant difference between scenarios 1 and 2. In the first scenario, there is a reduction in biodiesel consumption due to the increase in vegetable oil consumption, a smaller variation, of $16.31 \%$ for Argentina and Brazil (lower) and a greater variation of $22.99 \%$ in the case of China. On the other hand, this variation is significantly reduced in scenario 2 to $0.53 \%$ in Brazil and to $8.90 \%$ in the case of China. In analyzing scenarios 1 and 2 , it can be seen that the reduced consumption of soy-based biodiesel contributes to the greater impact of the meal and oil demand shock on soybean production in the analyzed regions (Table 4).

Scenario 3 considers the absence of biodiesel production and consumption, while the production of soybeans and the consumption of soybean meal and oil remain. Accordingly, this scenario considers the elimination of all policies to support the production and consumption of biodiesel. According to Table 4, soybean production declined in all regions, with the largest reduction observed in China (3.92\%) and a smallest reduction in the EU $(2.84 \%)$. In this scenario, prices decrease at all levels of production - soybeans, meal and oil leading to increased demand for soybean meal and vegetable oil (Table 4).

In scenario 4 we simulate the elimination of tariff barriers and subsidies only for soybean grain, meal and vegetable oil, while maintaining the support policies for biodiesel production. In this scenario, there are small variations in production, consumption and the prices of the products considered. Among the main producers in the world, such as Brazil and Argentina, there is an increase in production of $0.18 \%$ and $0.31 \%$, respectively. In the case of the USA and China, production decreases by $0.72 \%$ and $0.65 \%$, respectively. In the case of the USA, one of the largest producers of soybeans, production declines due to the elimination of subsidies for producers. For China, the largest consumer and importer of soybeans, there is a reduction in production due to the lower prices in the domestic market, caused by the free trade process (Table 4).

As described in the methodology, for a more detailed analysis of the price behavior two sets are compared for the three main soybean producer countries. In the first, the set of prices for Argentina, Brazil and the USA is shown, considering different demand shocks on the prices of meal, soybean oil and biodiesel and the elimination of soy-based biodiesel consumption. In the second group, the price changes between the base scenario and the free trade scenario are presented, with the elimination of tariff barriers and subsidies for soybeans.

Figure 1 shows the effects of a demand shocks of 5\% (DS-5), 20\% (DS-20) and 50\% (DS-50\%) on the consumption of meal, oil and biodiesel. In this same figure, the effects on the prices are presented considering the non-consumption of soy-based biodiesel. Considering a demand shock of $20 \%$, soybean prices in Argentina, Brazil and the USA increase by $33.3 \%, 32.6 \%$ and $30.5 \%$, respectively. In the case of soybean prices in Brazil, they go from US\$ 408 per ton in BS to US\$ 541 per ton in the scenario that predicts a $20 \%$ shock in demand. 


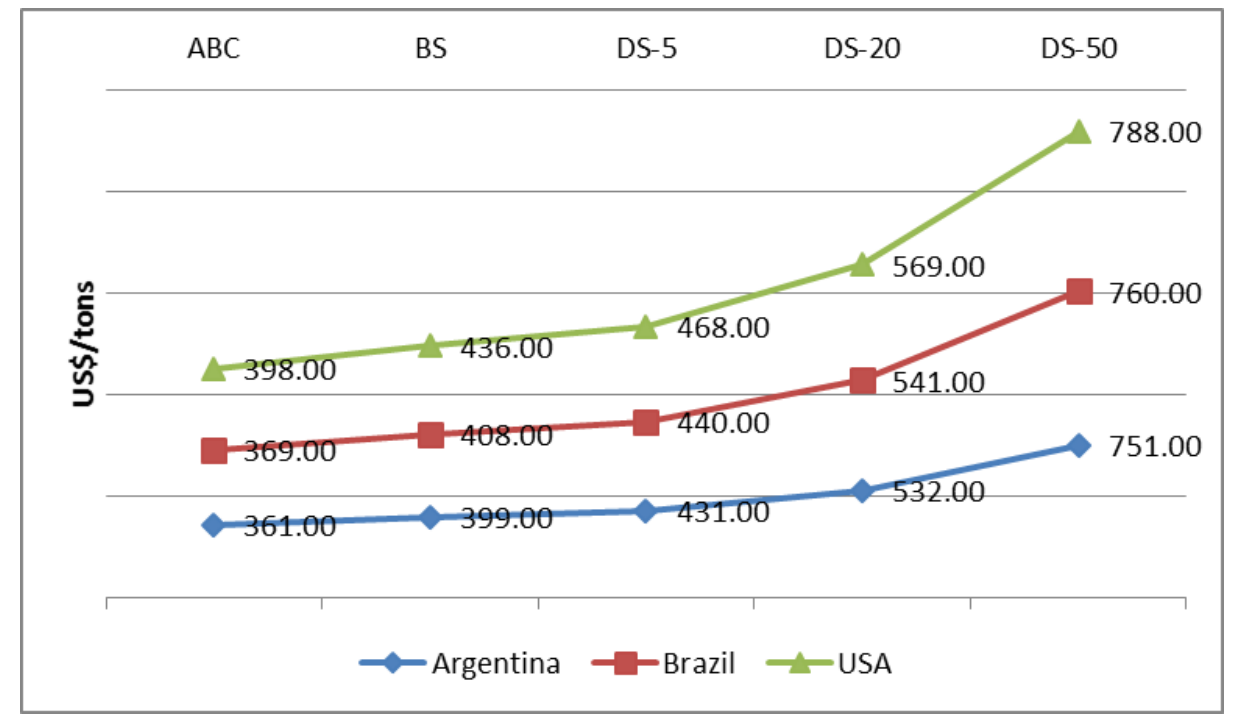

Figure 1. Soybean grain prices for Argentina, Brazil and the USA considering different demand shocks (5\%, 20\% and 50\%) and the absence of biodiesel consumption (ABC).

Source: research results.

When simulating the absence of biodiesel demand, soybean prices in Argentina, Brazil and the USA decrease by $9.5 \%, 9.6 \%$ and $8.7 \%$, respectively. In the Brazilian case, when considering the absence of demand for biodiesel, the price of soybeans is estimated to fall to US\$ 369 per ton. The maximum prices observed occur when considering a $50 \%$ demand shock, for Brazil, prices reach US\$ 760 per ton.

Figure 2 shows the effects of free trade on soybean prices for Argentina, Brazil and the USA. In this scenario, it can be seen that the effects on the prices derived from this simulation may be different depending on the country in question. Although for Argentina and Brazil there are a slight increase in the price of soybeans due to free trade, in the case of the US, the prices reduced from US\$ 436 per ton in the base scenario (BS) to US $\$ 428$ per ton in the free trade scenario (FTS). 


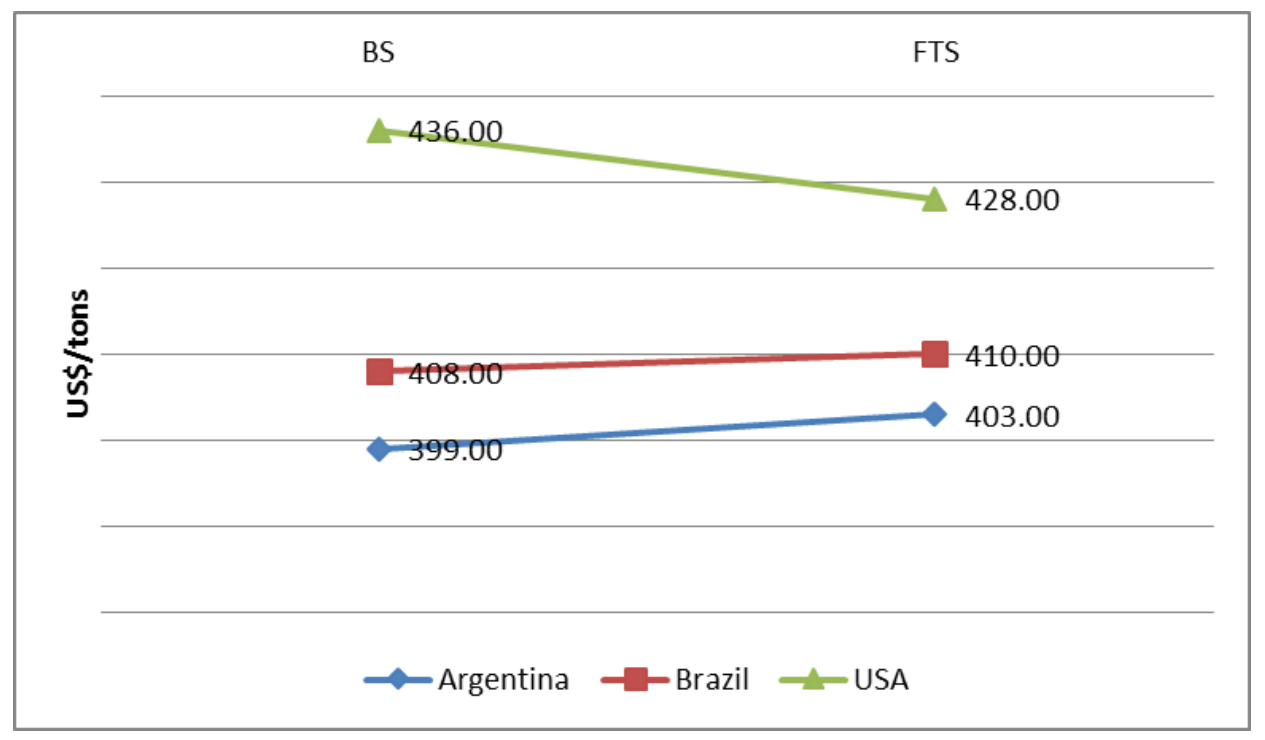

Figure 2 - Soybean grain prices for Argentina, Brazil and the USA considering the base scenario (BS) and the free trade scenario (FTS)

Source: research results.

In terms of prices paid to the soybean producer in the regions under consideration, the effects of free trade on prices are significantly smaller than the possible variations in the demand for meal, soybean oil and biodiesel. Unlike the trade policies applied to soybeans, meal and oil, mandatory and commercial policies to stimulate biodiesel production play a relevant role in the formation of soybean prices.

Considering prices in the three main soybean producers, the policies associated with the consumption and production of biodiesel allow a variation in the prices of soybeans in Argentina, Brazil and the USA of $9.52 \%, 9.56 \%$ and $8.72 \%$, respectively.

\subsection{Sensitivity Analysis}

Considering the two main analyzed groups, the next step is a sensitivity analysis of the model's parameters, evaluating the variations in terms of soybean production and consumption of meal, vegetable oil and biodiesel in the face of changes in the supply and demand price elasticities. To achieve this goal, positive and negative variations of $50 \%$ are simulated in the elasticities for scenarios 2 and 4.

The sensitivity analysis of the model's parameters aims to identify the changes in terms of production and consumption resulting from different reactions on the part of producers and consumers in face of price changes. Therefore, when different values are simulated for supply and demand elasticities, the possibility of differences arising from technological changes in production or marketing are considered, as well as changes in terms of consumer preferences.

The sensitivity analysis for scenario 2 shows that the changes in supply and demand elasticity $( \pm 50 \%)$ alter soybean production and oil and meal consumption by a maximum of $5 \%$. However, variations in biodiesel consumption are more significant, especially when 
simulating variations in the demand elasticities for biodiesel. For example, when simulating a reduction of $50 \%$ in the demand elasticity for biodiesel, its consumption increases by $12.5 \%$ compared to the original scenario 2. In this case, due to the higher consumption of biodiesel, there is a greater stimulus for soybean production and a reduction in the consumption of meal and oil due to the higher prices stimulated by the higher consumption of biodiesel.

Similarly, sensitivity analysis is performed for scenario 4, which simulates the elimination of tariffs and subsidies for soybean grain, meal and vegetable oil. In this scenario, the sensitivity analysis showed no variations greater than $4 \%$ for any of the products. Although variations in production and consumption were smaller, the observed variations in biodiesel consumption had the highest percentage of variation. In this scenario, the $50 \%$ positive change in the demand elasticity of biodiesel $(\mathrm{C} 4 \mathrm{DB}+50)$ leads to a $3.6 \%$ reduction in biodiesel consumption, while the $50 \%$ reduction in the same elasticity results in an increase of 2.12 in relation to the original scenario 4.

Finally, from the sensitivity analysis conducted in the two selected scenarios, it can be seen that the percentage changes in soybean production and in the consumption of meal, vegetable oil and biodiesel, are quite small in relative and nominal terms. In this sense, changes in the parameters of the supply and demand functions produce little change in the results obtained in each scenario, maintaining scenarios 1 and 2 in the best position in terms of potential increases in the supply of soybean grain.

\section{Conclusions}

The present article analyzed the impacts of soy-based biodiesel consumption on the soybean and derivatives market in the main producing and consuming countries. The results show that the greatest potential gains for soybean producers/exporters occur in the scenario that simulates an increase in the demand for food, considering the same rate of growth observed in the last ten years. The increase in income in developing countries, mainly in China, was reversed by increased demand for soybeans, used for the production of meal and vegetable oil.

The scenario that simulates the absence of demand for soybeans for biodiesel production, evaluates how the soybean market would be if there were no support policies for biodiesel production and consumption in the world. The results show that soybean prices would be $8 \%$ higher due to the demand for soybean for biodiesel production, which partially explains the higher soybean production observed in the last ten years.

The free trade scenario was not very promising. Even if all trade barriers and subsidies granted for the production of soybeans, meal and vegetable oil were eliminated, the effects on the production, consumption and trade of soybeans and derivatives would be significantly lower than the variations observed in the other analyzed scenarios.

In the long term, if the expected variations in demand in the scenarios analyzed continue for the next few years, and trade between the considered regions is stimulated by the lowering of trade barriers, there will be a need for the continued expansion of the supply of soybean and derivatives in the world. In this sense, Brazil and Argentina would be the two principal 
producing/exporting regions with the greatest potential to expand the supply of soybeans and derivatives.

The main contribution of this research is the finding that the incentives provided for the production and consumption of biofuels result in significant increases in the prices of agricultural and food products. However, the largest effect on the rise in soybean and oil product prices is due to the growth in demand in developing countries. This in turn determines not only a higher per capita consumption of food, but also the diversification of the diet, including more meats, dairy products and vegetable oils. This aspect contributes towards an increase in the demand for grains and oilseeds.

\section{References}

Barros, G. S. C., Silva, A. P., Ponchio, L. A., Alves, L. R. A., Osaki, M., \& Cenammo, M. (2006). Custos de Produção de Biodiesel no Brasil. Revista de Política Agrícola, ano XV, n.3. 36-50. Available:

https://www.embrapa.br/busca-de-publicacoes/-/publicacao/121643/custos-de-producao-de-bi odiesel-no-brasil. (December 7, 2017).

Bishop, P. M., Nicholson, C. F., \& Pratt, J. E. (2001). Tariff-Rate Quotas: difficult to model or plain simple. Wellington: NZIER. Available: http://www.nzier.co.nz. (December 15, 2016).

BITD (The International Customs Tariff Bureau). (2015). Tariffs Database. Available: http://www.bitd.org. (December 5, 2015).

FAPRI (Food and Agriculture Policy Research Center). (2014). Elasticities Databases. Available: http://www.fapri.org. (June 30, 2014).

Fliehr, O. (2014). Analysis of Transportation and Logistics Processes for Soybeans in Brazil. Thünen Working Paper 4. July 2013. Available: http://hdl.handle.net/10419/78249. (February $42015)$.

Gelder, J. W., Kammeraat, K., \& Kroes, H. (2008). Soy Consumption for Feeds and Fuel in the European Union. Profundo Economic Research. October 28. Available: https://milieudefensie.nl/publicaties/rapporten/soy-consumption-for-feed-and-fuel-in-the-euro pean-union. (February 15, 2015).

Josling, T., Blandford, D., \& Earley, J. (2010). Biofuel and Biomass Subsidies in the U.S., EU and Brazil: towards a transparent system of notification. IPC (International Policy Council) Position Paper, September. Available: http://www.agritrade.org/BiofuelSubsidiesUSEUBrazil.html. (December 12, 2014).

López, A., Ramos, D., \& Simkievich, C. A. (2008). Study of the Impact of China's Global Expansion on Argentina (Soybean value chain analysis: final report). Buenos Aires: CENIT. Available: www.uea.ac.uk/.../1.113468!2\%20ARGENTINA\%20SOYBEAN.pdf. (December 12, 2014).

Mandarino, J. M. G., Hirakuri, M. H., \& Roessing, A. C. (2015). Tecnologia para produção do óleo de soja: descrição das etapas, equipamentos, produtos e subprodutos. Londrina: 
Embrapa

Soja,

n.

171 ,

40p.

Available:

https://ainfo.cnptia.embrapa.br/digital/bitstream/item/126080/1/Doc171-OL.pdf. (March, 15, 2020).

Martin, W. (2019). Economic growth, convergence, and agricultural economics. Agriculture Economics, 50, 7-27. https://doi.org/10.1111/agec.12528

Nassar, A., Antoniazzi, L. B., Brandão, J., \& Moura, P. (2011). Soy Strategic Gap Analysis: Brazil and Argentina. São Paulo, Brazil: Institute for International Trade Negotiations. Available:

http://www.ifc.org/wps/wcm/connect/20a0cf004a95fc41ad32edeec99f439e/Soy+Gap+Analys is.English.pdf?MOD=AJPERES. (December 12, 2014).

Naylor, R. L., \& Higgins, M. M. (2018). The Rise in Global Production; implications for Food Security. Global Food Security, 16. 75-84. https://doi.org/10.1016/j.gfs.2017.10.004

Nicholson, C. F., \& Bishop, P. M. (2004). US Dairy Product Trade: Modeling Approaches and the Impact of New Product Formulations. Final Report for NRI Grant \# 2001-35400-10249, March. Available: https://pdfs.semanticscholar.org/a06b/5e16f2e46aa2bb794dcfa3cea3074525ae08.pdf. (March $15,2020)$.

OECD/FAO (Organisation for Economic Co-operation and Development - Food and Agriculture Organization of United Nations). (2015). The Agricultural Outlook Database. Available: http://www.oecd.org. (December 12, 2015).

Oliveira, A. L. R., \& Alvim, A. M. (2016). The supply chain of Brazilian maize and soybeans: the effects of segregation on logistics and competitiveness. International Food and Agribusiness Management Review, 20(1), 45-61. https://doi.org/10.22434/IFAMR2016.0084

Paris, Q., Drogué, S., \& Anania, G. (2011). Calibrating spatial models of trade, Journal of Economic Modeling, 28, 2509 - 2516. https://doi.org/10.1016/j.econmod.2011.07.008

Popp, J., Lakner, Z., Harangi-rálos, M., \& Fári, M. (2014). The Effect of Bioenergy Expansion: Food, energy, and environment. Renewable and Sustainable Energy Reviews, 32. 559-578. https://doi.org/10.1016/j.rser.2014.01.056

Pradhan, D. S., Shrestha, A., Mcaloon, A., Yee, W., Hass, M., \& Duffield, J. A. (2011). Energy Life-Cycle Assessment of Soybean Biodiesel Revisited. American Society of Agricultural and Biological Engineers, 54(3), 1031-1039. https://doi.org/10.13031/2013.37088

Rutheford, T. F. (1995). Extension of GAMS for complementarity problems arising in applied economic analysis. Journal of Economics Dynamics \& Control, 19, 1299-1324. https://doi.org/10.1016/0165-1889(94)00831-2

UNCTAD (United Nation Conference on Trade and Development). (2013). UNCTAD - Trains (Trade Analysis and Information System). Available: http://www.unctad.org. (December 15, 2014). 


\section{Macrothink}

Journal of Agricultural Studies

ISSN 2166-0379 2020, Vol. 8, No. 2

USDA-ERS (United State Department of Agriculture - Economic Research Service). (2014). Commodity and Food Elasticities. Available: http://www.ers.usda.gov/Data/Elasticities/query.aspx. (December 10, 2014).

WTO (World Trade Organization). (2011). Tariffs. Available: http://tariffanalysis.wto.org/default.aspx. (July 15, 2013).

\section{Copyright Disclaimer}

Copyright for this article is retained by the author(s), with first publication rights granted to the journal.

This is an open-access article distributed under the terms and conditions of the Creative Commons Attribution license (http://creativecommons.org/licenses/by/4.0/). 